\title{
A system monitoring operational safety of structures used in civil engineering
}

Janusz Juraszek

\begin{abstract}
The paper presents a system monitoring operational safety of structures used in civil engineering. The system is based on the fibre Bragg grating (FBG) sensors or sensors using the optical time domain reflectometry (OTDR) technology. The essence of the solution is to introduce FBG sensors into the structure to make them act as its "nervous system". The system may be implemented in existing civil engineering structures made of steel, concrete, reinforced concrete, as well as in shells and new structures at the design stage. The paper presents an example of an actual system operating based on FBG sensors and analysing the safety of Poland's longest steel footbridge. The footbridge is 35 years old. Periodic inspections of the Technical Inspection Office allow the footbridge operation if the structure meets the requirements stipulated by relevant regulations, but the decision is not based on a continuous analysis of the footbridge safety. The applied monitoring system makes it possible to analyse the footbridge operational safety on a continuous basis. The system informs about hazards, overloads, vandalizing acts, etc., and points to the need to take appropriate measures including the footbridge shutdown. The information concerning the state of safety may be sent on-line to any corner of the globe.
\end{abstract}

Keywords-safety of civil engineering structures, fibre Bragg grating, steel footbridge

\section{Introduction}

In the introduction the development of fiber Bragg gratings systems and the types of cranes and technical requirements were presented. The first works on the photosensitive fibers date back to Hill of 1978 [1]. However, the first practical application is related to the works of Meltz [2] of 1989. A complete monitoring system using FBG sensors was introduced in 1999-2003 [3]. Since then, a rapid development of this method in a wide range of practical applications has been observed. Patric et al. in [6] demonstrated that the technology of fiber optic sensors for strain, temperature and pressure developed in recent years is more effective as compared to traditional strain gauges. Guemes et al. [5] described the use of FBG sensors in composite materials in aircraft industry under electromagnetic noise conditions. Kamrujjaman Serker and Wu [2] used FBG sensors for monitoring the durability of bridge structures - structural health monitoring (SHM). FBG technique combined with multiplexing were deployed to monitor the blades of wind power plants in Japan (Eum et al [3]). On-line monitoring of temperature, deflection of $400 \mathrm{kV}$ power line was successfully implemented in a system based on Bragg sensors (FBG).

Janusz Juraszek, University of Bielsko-Biala Poland
The complete system has been installed on the ACSR conductor. In this way, continuous surveillance of thermal and mechanical loads of the power supply line was achieved. FBG sensors have also been used to monitor the intelligent structures $[3,4]$, which were characterized by high reliability, sensitivity, resistance to electromagnetic interference, small size and low weight. Analysis of the thickness of adhesive layer attaching the fiber optic sensors and strength parameters of the layer on the example of Kirchoff module were shown in [4]. New generations of smart coatings used in construction industry that enable implementation of Bragg gratings were presented in papers by W. Brachaczek [17-19]. B. Ahmad, T.J. Ali and R. A. Rahman presented the analysis of pressure changes in tanks using FBG sensors [7]. K. DRAGAN at the Fourteenth Australian International Aerospace Congress AIAC14 [8], pointed out the good correlation between the FBG method with other non-destructive methods at the example of detecting damage in the main rotor of a helicopter. It was also noted that the FBG sensors are fully accepted by specialists in the field of monitoring large construction, composite [9], aircraft designs. The overhead crane research was also carried out by Ladecki and Badura [21-22] using conventional strain gauges $[9,10]$.

\section{Monitoring of a footbridge deformation using fiber Bragg gratings}

Raising the level of safety of transport equipment, in particular handling equipment, often used for special purposes, forces the implementation of new technologies for building highly accurate measuring systems often with new unique properties. The dynamic development of optoelectronic technology based on light propagation in the fiber optic contributed to the creation of modern sensors for strain measurement, such as FBG (Fiber Bragg Gratings)

Pedestrian bridges are becoming slimmer, lighter, and more susceptible to vibrations caused by the wind, as well as humans. In contrast to the old materials from which traditional footbridges were designed, current technology allows the use lighter materials, but with greater strength. The fact is that the footbridges are of smaller cross sections during the initial tension, and for similar cross sections, their span is much greater. Thus, their transverse rigidity is reduced and they are more susceptible to vibration. As a result, implementing a precise analysis of the deformation has become necessary. Optical fiber sensors used for testing are placed in the half of the span length and also at the support number 3 . 


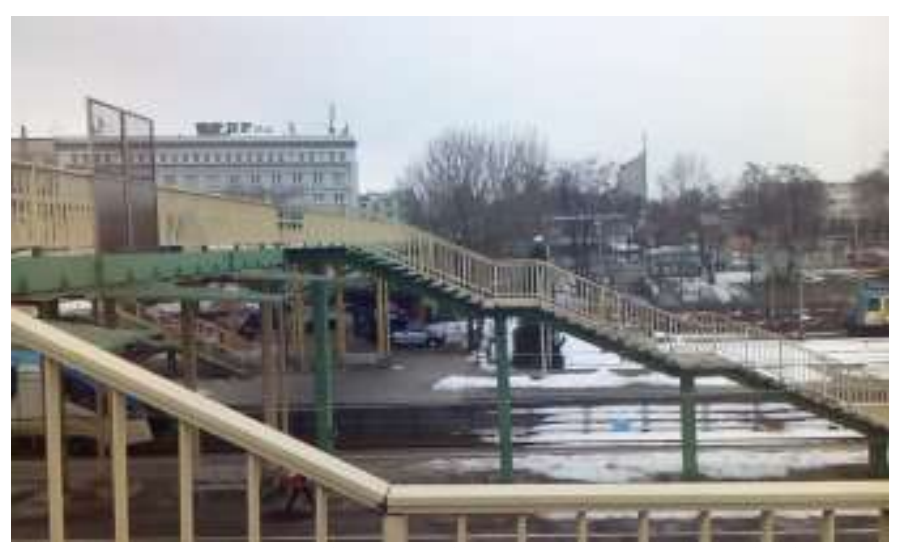

Fig. 1. The view from the bottom of the stairs structure of a footbridge in Bielsko-Biala - Source: own

TABLE 1. THE BASIC PARAMETERS OF THE FOOTBRIDGE IN BIELSKO-BIALA [12]

\begin{tabular}{|c|c|}
\hline total length of the platform & $273.80 \mathrm{~m}$ \\
\hline total width of the platform & $6.42 \mathrm{~m}$ \\
\hline usable width & $2 \times 2.82$ and $5.94 \mathrm{~m}$ \\
\hline $\begin{array}{c}\text { theoretical spans } \\
4 \times 20.00+10.10+3 \times 21.50+ \\
4 \times 23.00+4.00+3.20 \mathrm{~m}\end{array}$ \\
\hline $\begin{array}{c}\text { longitudinal slope (from the } \\
\text { axis 5) }\end{array}$ & $\mathrm{i}=1 \%$ \\
\hline cross slope & $\mathrm{i}=1.5 \%$ \\
\hline
\end{tabular}

The strain was measured using: FBG-scan optical interrogator, serial number SN10112601, and fiber optic sensors with Bragg gratings of the following wavelengths: $1546 \mathrm{~nm} ; 1546.5 \mathrm{~nm}$; $1541 \mathrm{~nm}$ [10-16]. The fiber optic system consists of: optical fiber sensors, communications optical fibers, connectors, devices for fiber optic beam exposure, fiber optic distribution system, a portable recorder and a system for adding signals.

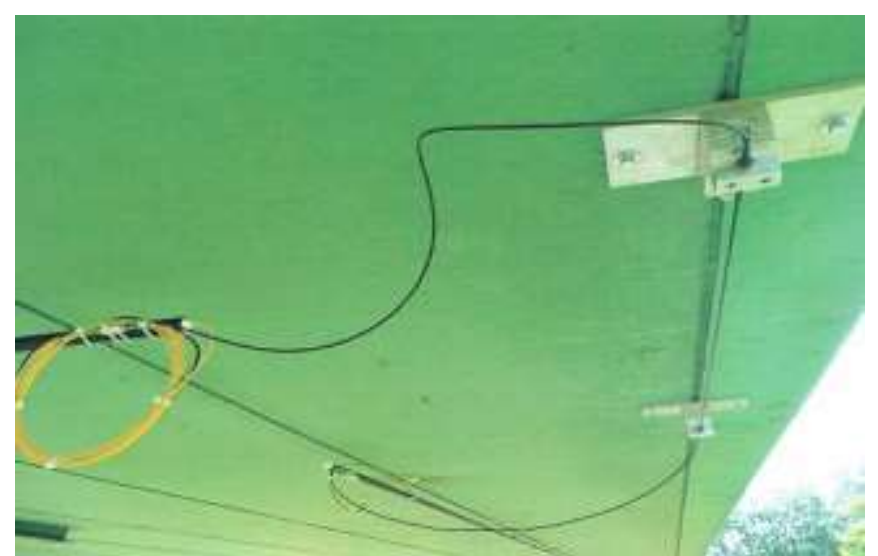

Figure. 2. A fiber optic sensor with a wavelength of $1546 \mathrm{~nm}$ fixed to special brackets bolted to the underside of the footbridge plate with adjustable tension of the sensor

\section{Description of the research process}

The study was conducted with the participation of a group of 56 pedestrians. It was carried out on span no. 3, where fiber optic sensors are attached. It consisted of several parts. The first step was to load the footbridge with a pedestrian group, walking along the span. Initially, the group covered the distance walking unevenly, and then walking in groups of 10 people - in synchronized teams. The next phase of the study was the monitoring of the footbridge loaded dynamically by the group running along the span. Runners were in groups of 10 , and then 20 people, and then an uneven running of the entire study group was performed. The last phase consisted of simulating the vandalism-type interactions. The group located in the middle of the span no. 3 performed even, synchronous jumps.

\section{Research results and discussion}

The results include values of deformation at selected points of the footbridge. The smallest footbridge deformation values 34 $\mu$ Strain were recorded during irregular march of the whole group.

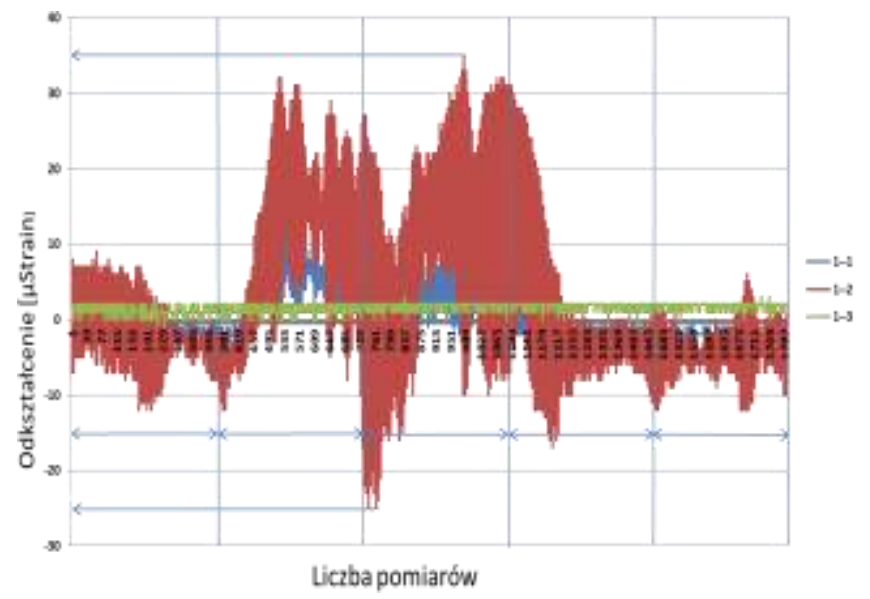

Fig. 3. Footbridge deformation chart. Stage I: TRIAL A - Source: own

When the entire group run through the footbridge, deformations has risen slightly to about $40 \mu$ Strain. 
Proc. of The Third Intl. Conf. On Advances in Civil, Structural and Mechanical Engineering - ACSM 2015

Copyright (C) Institute of Research Engineers and Doctors, USA .All rights reserved. ISBN: 978-1-63248-083-5 doi: 10.15224/ 978-1-63248-083-5-23

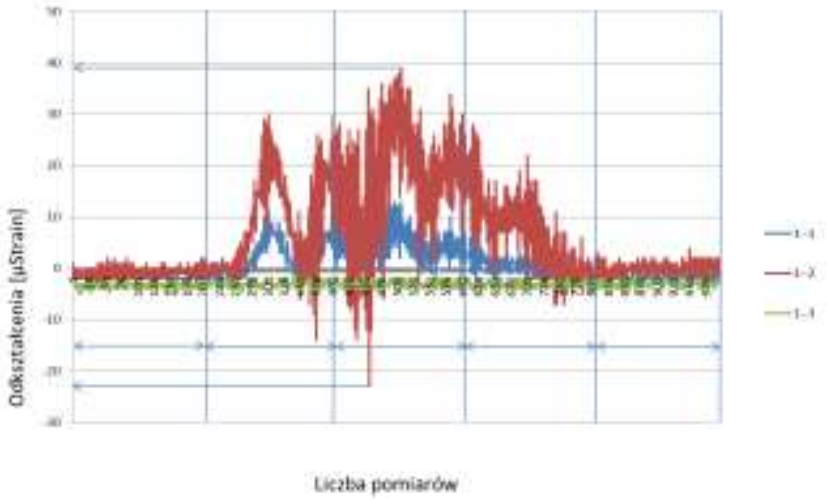

Fig. 4. Trial D - running through the footbridge

The greatest deformation value was recorded during a dynamic loading test with the participation of the test group (56 people) simulating vandalism behavior, which would lead to a dangerous swinging of the pedestrian bridge (PHASE III, TRIAL F). This deformation reached a value Sof $165 \mu$ Strain. The lowest deformation values were obtained during the march across the footbridge by a group of 10 people (PHASE II, TRIAL C), the results reached $34 \mu$ Strain.

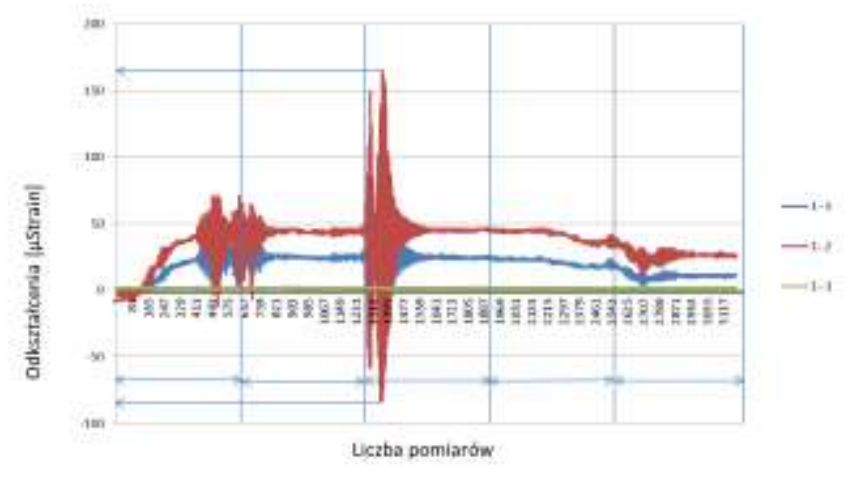

Figure. 5.Train F, vandalism behavior

\section{DISCUSSION OF THE RESULTS:}

- The system of Bragg sensors allows to carry out effective analysis of the footbridge deformation with a precision of up to $\pm 1 \mu$ Strain.

- Dynamic load of the footbridge caused by the vandalism action by a larger group of people may lead to a discomfort and be a nuisance for pedestrians staying on the bridge, and even prove dangerous to its supporting structure. In the final stage, they may even cause a construction disaster significantly.

\section{References}

[1] A. Selvarajan, "Fiber optic sensors and their applications," Indian institute of science, Bangalore-560 012, 2010.
[2] Z. Zhou, T. W. Graver, L. Hsu, and J. Ou, Techniques of advanced FBG sensors: fabrication, demodulation, encapsulation and their application inthe structural health monitoring of bridges," Pacific Science Review, vol. 5, no. 1, pp.116-121, 2003.

[3] Kin-tak Lau a, Libo Yuan a, Li-min Zhou a, *, Jingshen Wu b, Chung-ho Woo: Strain monitoring in FRP laminates and concrete beams using FBG Sensors a Composite Structures 51 (2001)

[4] B. Ahmad, T. J. Ali and R. A. Rahman, "Strain Measurements Using Fiber Bragg Grating Sensor," American Journal of Applied Science (Special Issue): pp. 40-48, 2005

[5] Thomas W. Graver, Luke Hsu,, Jin-ping Ou : Techniques of Advanced FBG sensors: fabrication, demodulation, encapsulation and their application in the structural health monitoring of bridges

[6] H. J. Patrick, G. M. Williams, A. D. Kersey, J. R. Pedrazzani, and A. M. Vengsarkar, "Hybrid fiber Bragg grating long period fiber grating sensor for strain/temperature discrimination," IEEE Photonics Technology Letters, vol. 8, no. 9, pp. 1223-1225, 1996.

[7] A.Adamiec, J.Juraszek J., M.Rams:, Zastosowanie MMM do analizy stref koncentracji naprężeń po wytłoczeniu dennicy, Mat. konf.: IV Międzynarodowa konferencja, Bezpieczeństwo pracy urządzeń transportowych w górnictwie, 5-7 listopada 2008, Ustroń.

[8] J.Deputat ., Podstawy metody magnetycznej pamięci metalu, Dozór techniczny, Nr 5/2002

[9] X.Ding, J.Li., F.Li F,: Magnetic memory inspection of high pressure manifolds, Mat. konf.: 5th International Scientific-Technical conference „Equipment and structures diagnostics using the magnetic memory of metal", 17-19 luty, 2009, Moskwa

[10] J.Juraszek , A.Grzywa: Praktyczne przyktady zastosowania metody magnetycznej pamięci metalu (MMPM). Monografia: Innowacyjność akademicka - nowe wyzwania dla nauki i przedsiębiorczości. Strona 5177.

2012. ISBN 978-83-62292-50-9

[11] J.Juraszek., A.Grzywa : Świattowody z siatka Bragga do pomiaru odkształceń metoda diagnostyczna XXI wieku. Monografia: Innowacyjność akademicka - nowe wyzwania dla nauki i $\begin{array}{lll}\text { przedsiębiorczości. } & \text { Strona } & \text { 77-93. }\end{array}$ ISBN 978-83-62292-50-9

[12] J.Juraszek. Innowacyjne, nieniszczące metody badań diagnostycznych ATH, 2013

[13] J.Juraszek, A.Grzywa, R.Żurek: Badanie próbek krzyżowych Metoda Magnetycznej Pamięci Metalu oraz Cyfrowej Korelacji Obrazu. Zeszyty naukowe BOSMAL Bielsko-Biała, Bielsko-Biała - kwiecień - 2015

[14] J.Juraszek., A.Grzywa: Badanie złaczy spawanych Metoda Magnetycznej Pamięci Metalu..V Międzynarodowa Konferencja bezpieczeństwa pracy urządzeń transportowych w górnictwie. Materiały konferencyjne.

Ustroń - listopad - 2015

[15] J.Juraszek., A.Grzywa.: Wykorzystanie nieniszczacej Metody Magnetycznej Pamięci Metalu do badania bieżni tożysk tocznych silników spalinowych oraz tożysk watów napędowych elektrowni wiatrowych.VI Międzynarodowa Konferencja bezpieczeństwa pracy urządzeń transportowych w górnictwie. Materiały konferencyjne. Ustroń - listopad - 2010

[16] A. Kawka: Zastosowanie metody magnetycznej pamięci metalu do badania stanu zmienności naprężeń $w$ cięgłach nośnych naczyń wyciagowych, Mat. konf.: IV Międzynarodowa konferencja, Bezpieczeństwo pracy urządzeń transportowych w górnictwie, 5-7 listopada 2008, Ustroń

[17] W. Brachaczek, The hydrophobicity of renovation plaster In manufacturing technology optimized by statistical methods, Construction and Building Materials, 49 (2013) 572-582.

[18] W. Brachaczek, The modeling technology of protective silicone coatings in terms of selected physical properties: Hydrophobicity, scrub resistance and water vapor diffusion, Progress in Organic Coatings Volume 77, Issue 4, (2014) 859-867.

[19] W. Brachaczek, Investigating the impact of silicone-organic polymers with different chemical structures on water vapour permeability in silicone paint coats, Progress in Organic Coatings Volume 77, Issue 4, (2014), 609-615,

[20] J.Łukaszewicz, Z.Łapiński Z., Badania metoda pamięci magnetycznej próbek stalowych poddanych naprężeniom zewnętrznym, Wojskowy Instytut Techniczny Uzbrojenia, Zeszyty naukowe, Nr 99/2015 
[21] Ładecki, B. Badura, S. Matachowski, F.: Strength analysis of a gantry crane of a coating structure, Mechanics and Control, 2012

[22] Ładecki B., Badura S., Matachowski F. 2010, Analiza eksperymentalna mostu przeładunkowego o konstrukcji powłokowej, XXIV Sympozjum Mechaniki Eksperymentalnej Ciała Stałego. Wrocław

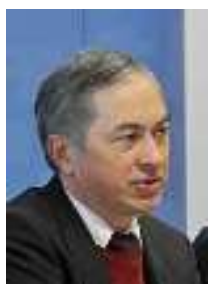

Professor Janusz Juraszek is Head of the Institute of Civil Engineering of the University of Bielsko-Biała. $\mathrm{He}$ deals with issues concerning operational safety in technology, including civil engineering and machine construction. He has proposed a system based on FGB sensors and optical fibres using the OTDR technology intended for monitoring the safety of structures used in civil engineering, machine construction and power engineering. The system is based on the residual magnetic field sensors and allows an analysis of operational safety of ferromagnetic structures, which is very important before first micro cracks arise. In 2014 in the USA he received the prestigious Horace Pubs award for the best publication on wire ropes. He also deals with smart materials with optical fibres using the FBG and the OTDR technologv. 